\title{
Foreign Bodies in Oceania
}

\section{Bronwen Douglas}

In the five decades after World War II, a critical historical conjuncture - the defeat of Nazism, the Cold War, decolonization, the civil rights movements in North America and Australasia, and the anti-apartheid movement - authorized antiracism to the extent that the word 'race' itself, in its naturalized scientific sense of a broad, hereditary human grouping, became all but unsayable in public and academic discourses in both the West and the Soviet bloc. Biologists and anthropologists denied the physical or cultural reality of races and predicted the demise of the concept. Postcolonial scholars made hybridity a privileged metaphor and censored race from their vocabularies for fear of sustaining abhorrent racial theories or imputing racism to actually or formerly colonized people. Human variation was uncomfortably euphemized as ethnicity, identity, religion, or culture. Yet the notion that racial differences are materially true and determine the physical, intellectual, moral, or social qualities of identifiable groups has hardly been challenged in popular opinion or conservative politics across the globe, while many indigenous people have appropriated the word race as a weapon in their lexicons of identity and understand the euphemisms in racial terms. ${ }^{1}$ With the Cold War finished but the ongoing legacies of racist regimes still evidently scarring the lives of victims and their descendants, with racial discrimination and persecution ongoing and racial scapegoating resurgent in the West, race has attracted renewed scholarly attention during the last decade or more and historians and philosophers are again charting the emergence, spread, illogic, and pernicious consequences of racialist thought. ${ }^{2}$

Notwithstanding this spirit of invigorated critical inquiry and some admirable scholarship on the history of race, anthropology, and geography, ${ }^{3}$ general histories of race tend to be inadequately grounded in rigorous vernacular reading of the original works of Euro-American thinkers whose broad, labile gamut of positions on human differences is often collapsed under the homogenizing rubric of racism. There is a parallel dearth of systematic comparison of diverse national discourses on race. ${ }^{4}$ In the twin contexts of these unexpected deficiencies in the comparative history of ideas and the near-total absence of detailed work on the history of race in Oceania as a broadly conceived region, ${ }^{5}$ the essays in this collection open up important new terrains for critical historical inquiry - on the science of race, Oceanic studies, and the intersections of the two. 


\section{Strategies}

Two striking elements of the idea of race are its slipperiness and the ontological realism it acquired during the nineteenth century, maintained in the face of fierce scientific and moral opposition during the late twentieth, and retained in conventional understandings virtually worldwide into the twenty-first. This volume challenges the naturalness of race by exposing its historicity and the tensions, incongruities, and fractures within or between shifting rival discourses on human similarity or difference. In the process, we probe the ambiguous conception of the modernist scientific notion of race in western Europe at the end of the eighteenth century; its subsequent normalization as an abstract system of knowledge, or raciology; its relationship to missionary and colonial praxis; and its instability, imprecision, and tenacity.

As historians of a potent and momentous concept, we treat ideas neither as purely abstract or discursive nor as a reflex of social relations and politics but as historically entangled with embodied human actions, including that of thinking - the word 'bodies' in the title is not mere rhetoric. ${ }^{6}$ The persons and actions that primarily concern us are conceived in terms of a dynamic feedback loop linking metropoles with antipodes: savants rarely travelled but read, measured, dissected, thought, talked, wrote, and published; travellers, missionaries, and colonial naturalists or anthropologists observed, collected, recorded, and sometimes theorized in the light of prevailing ideas and their own interactions with indigenous people; and the products of these engagements fed novel concepts of human difference that both participated in and percolated into wider public spheres. By this logic, the idea of race was enmeshed in the interplay of unstable discourses and particular European experiences of encounters with non-European people, places, and things. Current ideas about human diversity were enacted and often transformed in such encounters which generated much of the evidence on which theorists relied to illustrate their deductions.

Our aim is not to explain racial thinking in causal terms but to convey an open-ended sense of the fertile, provisional, material transactions of persons, ideas, discourses, contexts, and their permutations, combinations, and performances. Spurning such an approach, the cultural geographer Kay Anderson chided me, along with George Stocking, Jr., Nancy Stepan, and other historians, for 'overgeneralisation' and for having hazarded 'no explanation' of the shift from Enlightenment humanism to nineteenth-century innatism. Yet this is a deliberate strategy, not an oversight. As an historian, I reject facile monocausal explanations such as Anderson's quite inadequate contention, based almost exclusively on a reading of anglophone literature, that 'race's founding' can be reduced to a 'crisis of humanism' precipitated by British colonial encounters with Aboriginal 'intractability'. ${ }^{7}$ While we acknowledge that science is neither hermetic nor autonomous, we refuse to explain away the science of race as a 
simple effect of particular European discourses or social, political, or colonial circumstances. Contending that the interrelationships of science and society are not merely reflective, linearly causal, or even dialectical, we see the science of race and colonialism as parallel but porous domains of praxis, each with its own 'internal rhythm' and linked by complex, ambiguous intersections and exchanges. ${ }^{8}$

This grounded method for doing intellectual history requires detailed empirical ballast which in turn dictates a regional, rather than a global focus. Our regional focus on Oceania has both historical and pragmatic warrant: it acknowledges the considerable salience of indigenous Oceanian people in the natural history of man and the emergent science of race, ${ }^{9}$ out of all proportion to their limited political, material, or demographic import to Europe; and it fits the research interests of the contributors. The term 'science of race' refers to systematic efforts made in various branches of natural history - particularly comparative anatomy, physiology, and zoology - to theorize physical differences between human groups as innate, morally and intellectually determinant, and possibly original. Such endeavours coalesced in the new disciplines of biology and anthropology which drew major stimulus from the rich stocks of information and objects repatriated from Oceania by scientific voyagers from the late 1760s.

Chronologically, we probe racial thinking in general and with specific relation to Oceania during a key era - the heyday of the scientific concept of race from its emergence in the second half of the eighteenth century until the outbreak of World War II. These two centuries encompassed important transitions in both global discourses and regional interactions. Globally, inchoate Enlightenment ideas about varieties within a common humanity metamorphosed into a ubiquitous but contested science of race which reified races as tangible markers of inherent somatic differences. Regionally, an uneven but steady contextual shift saw residence or settlement overlap and finally displace voyages as the dominant setting for European engagements with and knowledge of Oceanian people. The first of these transitions is the major theme of Part One; while the second weaves through Parts Two to Five.

\section{Naming spaces}

We apply 'Oceania' historically to the vast insular zone stretching from the Hawaiian Islands in the north, to Indonesia in the west, coastal Australia and Aotearoa New Zealand in the south, and Easter Island in the east. This extended sense reinstates the cartographic vision of the French geographers and naturalists who invented the term and transcends its restriction to the Pacific Islands in much later anglophone usage, including recent strategic appropriations by indigenous intellectuals concerned to negotiate postcolonial identities. ${ }^{10}$ As originally conceived, Oceania embraced the Asian/Indian/Malay Archipelago 
or East Indies (the island of Borneo, modern Indonesia, Timor-Leste, Singapore, and the Philippines), New Guinea (modern Papua New Guinea and the Indonesian provinces of Papua and West Papua), New Holland (mainland Australia), Van Diemen's Land (Tasmania), New Zealand (Aotearoa), and the island groups of the Pacific Ocean (soon to be distributed between Melanesia, Micronesia, and Polynesia). The two centuries spanned by this volume comprise only a small, recent, mostly colonial fraction of the more or less immense length of human occupation of these places, estimated by archaeologists to range from as much as 65,000 years in Australia (and presumably earlier in Island Southeast Asia) to fewer than 800 years in Aotearoa. ${ }^{11}$

In 1804, Edme Mentelle (1730-1815) and Conrad Malte-Brun (1775-1826) coined the name Océanique, 'Oceanica', as a more precise label for 'this fifth part of the world usually grouped under the generic name of Terres australes', or 'southern lands'. The French term had pluralized Terra Australis incognita, the fifth continent of cartographic imagination since the early sixteenth century. ${ }^{12}$ In 1756, the littérateur Charles de Brosses (1709-1777) proposed a geographic tripartition of this 'unknown southern world'. Polynésie (from Greek polloi, 'many') denoted 'everything in the vast Pacific Ocean' and encompassed what are now Polynesia, Micronesia, and much of Island Melanesia. Australasie (from Latin australis, 'southern') was located 'in the Indian Ocean to the south of Asia' and lumped hypothetical vast unknown lands together with actual places seen by voyagers in New Guinea, New Holland, Van Diemen's Land, New Zealand, and Espiritu Santo (in modern Vanuatu). Magellanique - a synonym for Terra Australis in earlier cartography — was for Brosses a purely speculative land mass stretching to the south of South America. ${ }^{13}$ Mentelle and Malte-Brun retained only Polynésie from Brosses's nomenclature but, whereas Brosses had made it an umbrella label for the 'multiplicity of islands' in the Pacific Ocean generally, they contracted it to what would become Polynesia and Micronesia and substituted Océanique for the regional whole. In 1815, Adrien-Hubert Brué (1786-1832) in turn amended Océanique to Océanie, 'Oceania' (Figure 1). ${ }^{14}$ In 1832, the navigator-naturalist Jules-Sébastien-César Dumont d'Urville (1790-1842) lent his considerable empirical authority to the name and broad geographic span of Océanie and in the process initiated the distribution of the Pacific Islands and their inhabitants between Melanesia, Polynesia, and Micronesia (Figure 2). Dumont d'Urville's terminology was formally adopted by the French Navy and popularized by his rival classifier Grégoire Louis Domeny de Rienzi (1789-1843), author of the highly derivative but widely-read Océanie ou cinquième partie $d u$ monde, 'Oceania or Fifth Part of the World' (1836-8). ${ }^{15}$ 
Figure 1: Adrien-Hubert Brué, 'Océanie ou cinquième partie du monde comprenant I'Archipel d'Asie, I'Australasie, la Polynésie, \&. ${ }^{a}$... 1814' . ${ }^{16}$

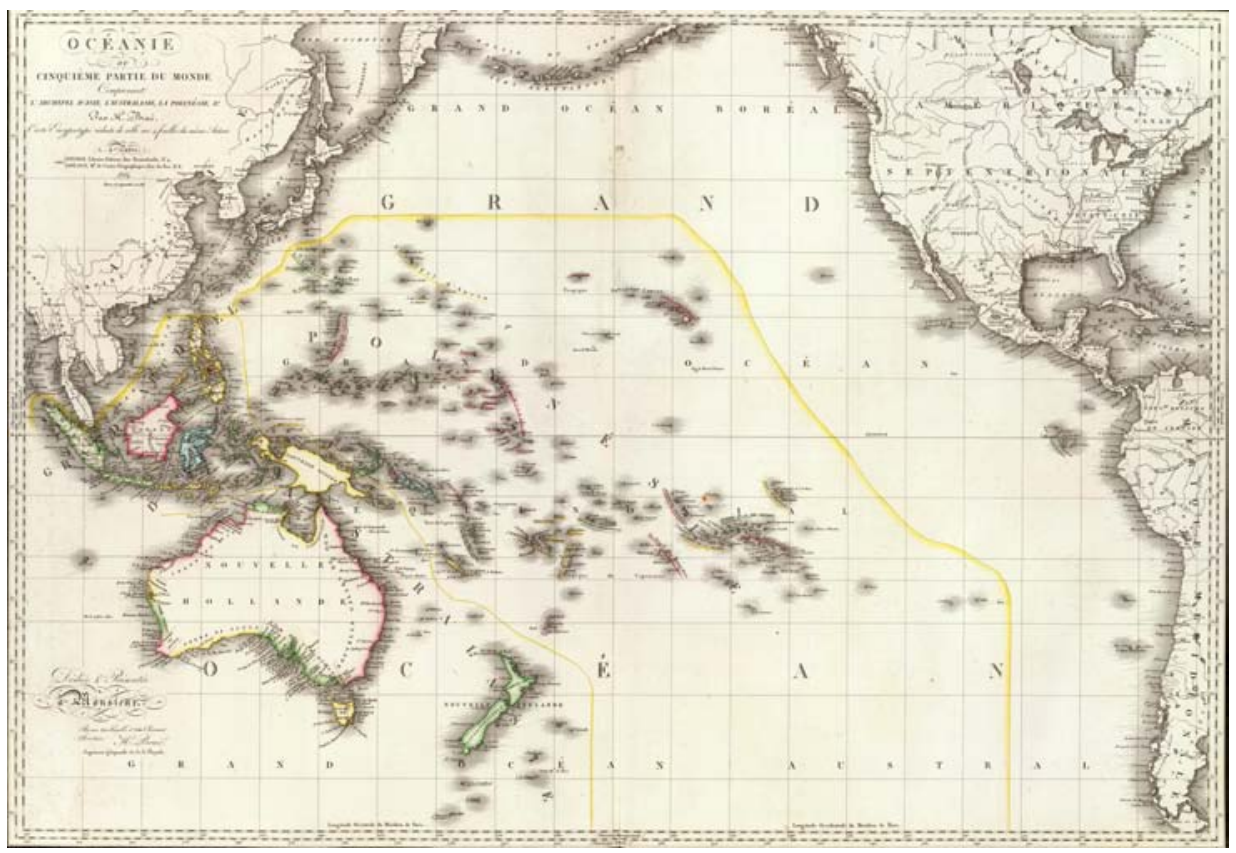

Engraving. David Rumsey Map Collection. Fulton, MD: Cartography Associates.

'Oceanica' evidently entered English in the 1820s via a translation of Malte-Brun's Universal Geography (1825) and was borrowed in the 1840s by two distinguished anglophone writers. The American philologist and ethnologist Horatio Hale (1817-1896), a member of the United States Exploring Expedition to the Pacific in 1838-42, made it his general label for all the land 'between the coasts of Asia and America', including New Holland and the 'East Indian Archipelago' (1846:3). And the British ethnologist James Cowles Prichard (1786-1848) found it the logical name for 'all the insulated lands that have been discovered in the Austral Seas', as far as and including Madagascar. A decade earlier, Prichard had occasionally used the phrases 'Oceanic race', 'nation', or 'tribes' but at that time limited 'Oceania' to 'the remote groupes' of Pacific Islands - a usage derived from the idiosyncratic racial taxonomy published by the French naval pharmacist and naturalist René-Primevère Lesson (1794-1849) following his voyage round the world on the Coquille in 1822-25. Lesson had restricted 'Océanie properly speaking' to what is now called Polynesia and applied what might have been an early Portuguese usage of Polynésie to denominate the 'Asian archipelagoes', including New Guinea. ${ }^{17}$ By contrast, British Evangelical missionaries who proselytized in the Pacific Islands from 1797 resisted the new French geographical labels until late in the nineteenth century but retained Brosses's ocean-wide span for Polynesia, only splitting 'Western' from 'Eastern' 
Polynesia in the late 1830s in anticipation of their imminent encounter with a 'decidedly distinct', 'negro race' in the islands west of Fiji. ${ }^{18}$

Figure 2: Ambroise Tardieu, 'Carte pour l'intelligence du mémoire de M. le capitaine d'Urville sur les îles du grand océan (Océanie)' ${ }^{19}$

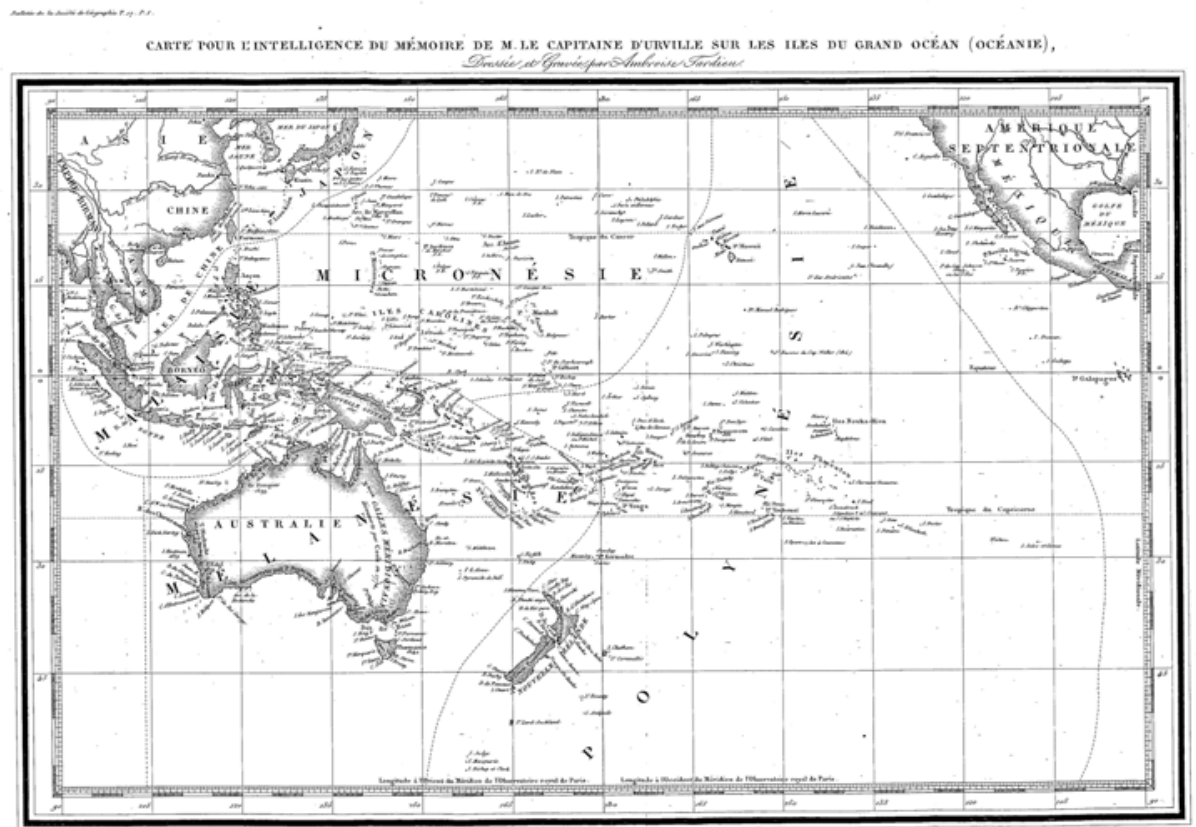

Engraving. Photograph B. Douglas.

\section{Classifying people}

From the outset, Océanie was internally racialized, with skin colour and physical organization the key differentiae in the elaboration of region-wide racial taxonomies. Mentelle and Malte-Brun located the 'very beautiful', 'copper-coloured', 'Polynesian race' in what are now Polynesia and Micronesia and assigned it 'common origin' with 'the Malays of Asia'. They sharply differentiated 'the Polynesians' from the 'black race, that we can call Oceanic Negroes', which inhabited New Guinea, Van Diemen's Land, and what is now Island Melanesia, and from a probable 'distinct third race' in New Holland which they ranked 'only a single degree above the brute' and likened to 'the apes'. Malte-Brun reasoned that the 'tanned' and the 'black' races must issue from 'two stocks as dissimilar in physiognomy as they are in language, namely, the Malays or yellow Oceanians, and the Oceanic Negroes' ${ }^{20}$

In 1825, the French soldier and biologist Jean-Baptiste-Geneviève-Marcellin Bory de Saint-Vincent (1778-1846) took the radical step of dividing the human genus into fifteen separate espèces, 'species'. He called his seventh espèce 
'Neptunian' and divided it between three races: 'Malay'; 'Oceanic' (the present-day Polynesians); and Papou, 'Papuan',' 21 a 'hybrid' product of the alliance of Neptunians and 'Negroes of Oceanica'. The Papous were 'the most truly savage of all Men' along with Bory's eighth espèce, named 'Australasian' and mostly comprising mainland Aborigines. Australasians were 'the most brutish of Men', 'totally foreign to the social state', 'misshapen', and with 'the most deplorable facial resemblance' to mandrills. Bory's penultimate espèce reconfigured the Negroes of Oceanica as Mélaniens, a term derived from Greek melas, 'black', referring explicitly to skin colour. This species included the inhabitants of Van Diemen's Land ('timid, stupid, idle'), most of what is now Melanesia ('warlike and anthropophagous to the highest degree'), and remote areas of the larger islands of the Malay Archipelago ('hideous Men'). ${ }^{22}$

Bory drew effusively for this part of his taxonomy on two key voyage texts: Lesson's contributions to the Zoologie of the Coquille expedition; and the Zoologie of the Uranie voyage (1817-20) produced by the naval surgeon-naturalists Jean-René Constant Quoy (1790-1869) and Joseph-Paul Gaimard (1793-1858) Bory used 'Oceanic' in Lesson's restricted sense and owed his concept of hybridized Papous to Quoy and Gaimard. ${ }^{23}$ Lesson (1829), a more ambitious classifier than most of his naval colleagues, divided 'the various Oceanians' (here using the term in its broad sense) into a tripartite racial hierarchy on the basis of physical organization, customs, presumed origins, and gross corporeal affinities. His 'lst race', 'Hindu-Caucasic', derived from the Indian subcontinent and was divided between a 'Malay branch' and an 'Oceanian' one (present-day Polynesians) which he thought physically 'superior' to other South Sea Islanders. His '2nd race', 'Mongolic', was located in what is now Micronesia. His '3rd race', 'Black', was split into two branches: the 'Caffro-Madagascan' comprised a Papou variety inhabiting the New Guinea coast, nearby islands, and present-day Island Melanesia and a 'Tasmanian' variety in Van Diemen's Land; while the Alfourous occupied New Holland ('Australians') and the interior of New Guinea and some islands of the Malay Archipelago ('Endamênes'). ${ }^{24}$ Neither Papou nor Alfourou was a new term. In the early sixteenth century, Papua was a local toponym for islands to the west of New Guinea which Portuguese and Spanish travellers extended to the 'black' inhabitants of those islands and the New Guinea mainland. From the late eighteenth century, it was often generalized to 'black' Oceanian people as a whole. So-called Alfourous (Alfours, Alfoërs, Haraforas, etc.) were a recurrent, if elusive presence in Portuguese, Spanish, Dutch, French, and British colonial imaginaries from the sixteenth to the twentieth centuries. ${ }^{25}$

Dumont d'Urville's (1832) ethnological classification is more streamlined than these convoluted schemas, though no less racialized. He divided the inhabitants of Oceania into 'two distinct races' on the basis of skin colour, physical appearance, language, political institutions, religion, and reception of Europeans. 
Dumont d'Urville reworked Bory's term Mélanien into Mélanésien, 'Melanesian', as his general name for the 'black Oceanian race' which he found 'disagreeable' and 'generally very inferior' to the 'copper-coloured race' of 'Polynesians' and 'Micronesians' and to the 'Malays'. The 'Australians' and the 'Tasmanians' were at the base of this racial hierarchy as 'the primitive and natural state of the Melanesian race'. ${ }^{26}$ The racial implications of Dumont d'Urville's cartography were taken for granted in 1834 by Charles Monin (18?-1880) whose map of 'Océanie' overlaid the 'division adopted by the geographers' into Polynesia, Australasia, and the Indian Archipelago with Dumont d'Urville's 'division by race of men' (Figures 3, 3a). By 1830, few Euro-Americans would have disputed Dumont d'Urville's presumption of the material reality of discrete, physically defined, differentially endowed human races, though the origins, import, and future implications of racial distinctions were bitterly contested. His racial nomenclature for Oceania was quickly adopted in France but was viewed ambivalently by many anglophone writers. The American Hale (1846:3-116) fully embraced it and lauded the 'propriety' of correlating geographical 'departments' with 'the character of their inhabitants'. In mid-century, the Anglican Bishop of New Zealand, George Augustus Selwyn (1809-1878), appropriated Dumont d'Urville's neologism to name the Melanesian Mission, his peripatetic evangelistic enterprise in the southwest Pacific. Selwyn sometimes also used the term as a linguistic and racial label but, unlike the Frenchman, did so non-pejoratively, maintaining 'that civilization is a mere name, and that religion is the only real ground of difference between the various races of mankind'. ${ }^{27}$ Robert Henry Codrington (1830-1922), a subsequent head of the Melanesian Mission, used Melanesian and Polynesian as anthropological labels but limited Melanesian to the island groups east and southeast of New Guinea. He too refused the idea of racial hierarchy. Prichard, in contrast, rejected Dumont d'Urville's wording - Melanesian lacked 'etymological accuracy' and should be replaced by 'Kelænonesian' — but rehearsed his invidious racial discrimination: 'the black races in Oceanica' were 'very different from' and 'very inferior to the Malayo-Polynesians'. ${ }^{28}$ 
Figure 3: Charles V. Monin, Océanie: divisions de l'Océanie. ${ }^{29}$

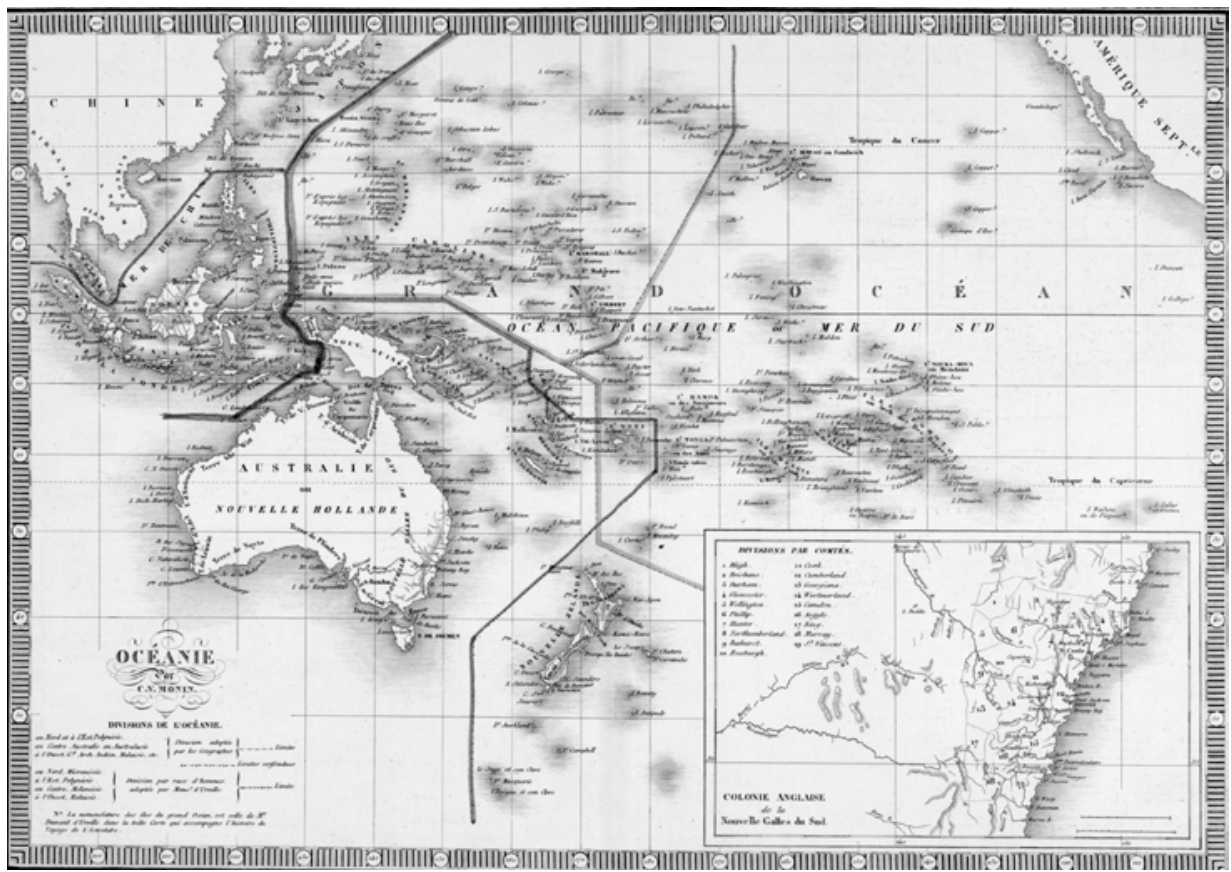

Engraving. MAP T 913/2. Canberra: National Library of Australia.

Figure 3a: Charles V. Monin, Océanie: divisions de /'Océanie, detail. ${ }^{30}$

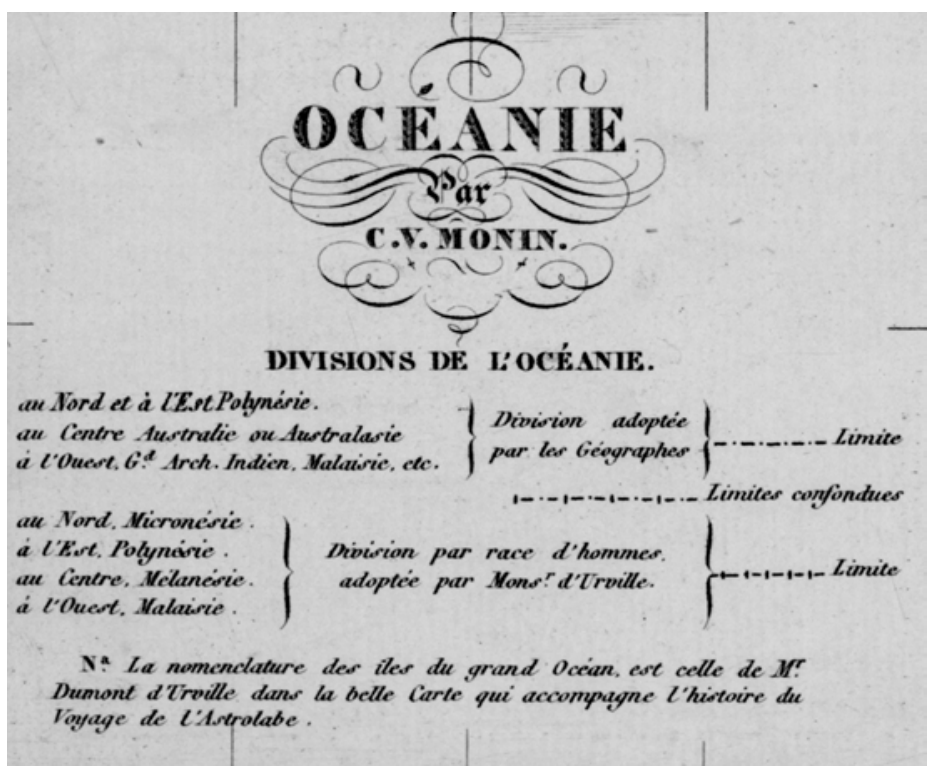

Engraving. MAP T 913/2. Canberra: National Library of Australia. 
For much of the nineteenth century, English racial terminologies for Oceanian people were more varied and ambiguous than French, due in part to differing emphases in the respective fields of inquiry. In Britain, the science of man had strongly philanthropic roots and drew much empirical sustenance from missionary ethnography. ${ }^{31}$ In France, the science of race was a highly deductive outgrowth of biology and physical anthropology, fed by the work of travelling naturalists. ${ }^{32}$ Yet, notwithstanding principled humanitarian antipathy to the dehumanizing tendencies of the science of race, English writings on man were steadily infiltrated by racial logic and language. The authors of works on Oceania, including missionaries, routinely differentiated the 'black' 'Polynesian negro' from the 'brown' or 'copper-coloured' 'proper Polynesian', or the 'Papuan' race from the 'Malayo-Polynesian' race, before normalizing varieties of Dumont d'Urville's binary system late in the century. ${ }^{33}$

\section{Oceania}

Océanie retained both its breadth and its racial connotations in French usage well into the twentieth century. ${ }^{34}$ By this stage, 'Oceania' was fairly common in English and just as racialized despite its narrower geographic span (see note 10). In 1920, the Foreign Office handbook on British Possessions in Oceania differentiated Pacific Islanders along explicitly social evolutionist racial lines: Solomon Islanders were 'a Melanesian race, still largely in a state of barbarism' and 'naked savages scarcely beyond the head-hunting stage of development'; whereas Tongans were 'a branch of the Polynesian race', 'a highly advanced native race who have accepted Christianity'. ${ }^{35}$ By the 1970s, with the public discrediting of racial language, the regional name had shed overt intimations of race in both French and English. In French, Océanie had contracted in conformity with the international geopolitical norm that puts the Malay Archipelago in Asia and divides Asia from Oceania along the arbitrary colonial border which cuts the island of New Guinea in two. ${ }^{36}$

Recuperation of the broader early conception of Oceania suits our ethical, political, and intellectual interests. Ethically, we seek to expose the old racial implications of the term to rigorous historical critique. Politically, an inclusive construction of Oceania unsettles the unquestioned realism of the postcolonial national and ethnic boundaries that were inherited from colonial divisions and are further reinscribed in the partitioning of academic research. Historically, our terminology acknowledges farflung cultural and linguistic affinities, notably between Austronesian-speaking groups, and the trajectories of settlement and other human movements in the region, including those of Europeans, before the congealing of colonial borders in the late nineteenth century. At least until the 1880s, the indigenous inhabitants of New Holland/Australia and Van Diemen's Land/Tasmania were usually compared, classified, and ranked within the same regional frame as people labelled Malays, Polynesians, Micronesians, Melanesians, 
Oceanic Negroes, or Papuans. And Oceania loomed large in its own right in the history of racial thinking: Oceanian experience and examples were central to the biologization of the idea of race from the late eighteenth century (see Chapters Two and Three); racial comparisons within Oceania and case studies from the region, especially Aboriginal Australia, figured prominently in the nineteenth-century appropriation of anthropology by the science of race and in qualified humanitarian opposition to the union (see Chapters Two, Four, Five, Six, and Seven); and the region contributed to science's rejection of race from the mid-twentieth century, notwithstanding entrenched popular beliefs and vocabularies and the naturalization of Dumont d'Urville's racial categories in modern indigenous usages. ${ }^{37}$

\section{Foreign bodies}

Apart from signalling historical particularity and embodiment, our use of the term 'foreign bodies' is deliberately ambiguous and ironic. As foreign bodies in Oceanian contexts, European and other travellers, missionaries, or colonizers were received unpredictably, sometimes with joy and hospitality but also with indifference, ambivalence, fear, rejection, or hostility. Indigenous reception helped shape the attitudes, reactions, and representations of visitors who in turn impinged to a greater or lesser extent on local patterns of action, relationship, and understanding. As foreign bodies in European representations, comparisons, classifications, and collections, indigenous Oceanian people were usually objectified and measured as specimens. Ultimately encompassed by colonial empires, indigenous bodies became colonial subjects and were often alienated from their own places - rendered foreign - especially in settler colonies.

It is nonetheless important to resist the distanced binary perspective which represents imperial and colonial encounters as the asymmetric opposition of discrete homogeneous communities, one local and subordinate, the other foreign and dominant. ${ }^{38}$ Close attention to particular past situations, always messy and multiplex, reveals overlapping alliances between local people and foreigners whose respective social and cultural groupings intersected ambiguously and fractured internally along lines of gender, age, vocation, place, interest, and rank, class, or status. Moreover, the foreigners in such encounters were often not Europeans but other Oceanian people - travellers, labourers, missionaries, native police, health workers, other colonial appointees, and so forth. One product of indigenous liaisons with foreigners was the engendering of significant populations of mixed ancestry, further complicating the quixotic colonial quest for racial purity (see Chapters One and Eight).

Notwithstanding these caveats, this volume is not per se a history of encounters in Oceania but a history of the idea of race with specific reference to that region. Our major concern, with varying relative emphasis, is the 
entanglement of discourse and experience with respect to race. Experience was grounded in encounters, where racial ideas and representations were enacted, reworked, or forged, but the level of generality at which the collection is necessarily pitched means that particular embodied encounters figure only fleetingly as examples. ${ }^{39}$ Our core themes are variety, flux, ambiguity, contestation, and recursion in the concept of race as well as in the exemplary representations and appropriations of indigenous Oceanian people and their bodies made by savants and scientists, field naturalists and collectors, colonial officials and humanitarians, settlers and missionaries. Our wide thematic net thus traces the threads of scientific conceptions of race into political, philanthropic, and public domains. We position race not only in relation to biological and anthropological discourses but also colonial and government policies, popular stereotypes, and equivocal humanitarian engagements with the idea of race and its science. We foreground ideological fractures and national, class, and personal variations which rendered European racial ideas and representations anything but homogeneous or consistent. But we also chart the ongoing, if now largely illegitimate appeal of the race concept, its chameleon capacity to take on the colouring of the time and the place, and its propensity to recur in the face of the most determined efforts to invalidate or extirpate it.

\section{The chapters}

Parts One and Two of this book set the global, regional, and empirical scenes for the remainder of the volume and constitute an original contribution to the history of ideas. In two substantial chapters of very different focal lengths, Bronwen Douglas investigates comparatively the formulation of the modernist concept of race in Germany and France; the scientific consolidation of racial theory in France, Britain, and the United States from the mid-eighteenth century to about 1880; transnational flows of ideas about human origins, unity or diversity, and racial mixing; and the relationships of theory to evidence derived in a particular field. Chapter One is a history of a European idea. By synthesizing a wide range of contemporary materials, it shows how the biologization of an older, genealogical conception of race in western Europe at the end of the eighteenth century enabled starker differentiations between essentialized extended human groups and paved the way for a normal science of race spanning a broad range of moral and theoretical positions. This remarkably tenacious paradigmatic set was not dislodged until the mid-twentieth century and its fallout endures worldwide. ${ }^{40}$ Chapter Two particularizes the history of race in the light of the prolific empirical legacy of scientific voyaging in Oceania, the growing force of the taxonomic impulse, and the recurrent tension between global theoretical systems and regional facts. Through a focus on the interrelationships of selected savants and travelling naturalists, of deductive and empirical knowledge, this chapter probes the reciprocal significance of 
metropolitan discourses and Oceanic field experience for competing schools of the hardening science of race, as the orthodox doctrine of a single human species steadily lost ground to the mounting conceivability of polygeny - the belief in plural human origins or multiple species.

In Chapter Three, Chris Ballard addresses the middle phase of the irregular trajectory from voyaging to residence to colonial settlement as the primary conduit for the collection and deployment of information about indigenous Oceanian people. With particular reference to New Guinea, he maps a transition in heuristic authority between the 1820s and 1870: from distanced early colonial observers in the Malay or Indian Archipelago, whose imagined cartographies of human difference rested on haphazard temporal and spatial contrasts between the 'brown' Malay race and the 'Oceanic Negroes' or Papuans, to a new mid-nineteenth-century model of the terrestrial natural scientist engaged in longterm field observation under broad colonial aegis, embodied in the figure of Alfred Russel Wallace. Wallace, championing the scientific method, insisted on direct visual contact and the presence of the observer. Yet his concern for the correct identification of boundaries for human, as well as zoological distributions both presumed and prefigured key debates on the origins of pure racial types. The chimeric ideal of racial purity became a focal concept through an increasing emphasis on the 'problem' of racial mixing between Malay and Papuan.

Part Three takes the science of race into colonial settings, with specific attention to the importance of knowledge about Aboriginal Australian bodies, both living and dead, in the developing disciplines of anthropology in Britain and France; and to the negative implications for Aboriginal people of hardening conceptions of race. In Chapter Four, Paul Turnbull takes issue with the conventional narrative that attributes scientific lust for Aboriginal anatomical specimens solely to Darwinians anxious to confirm the evolution of humanity by speciation. He shows that Darwinians and their opponents, metropolitans and colonials, all engaged in bitter competition to acquire Aboriginal bodily remains for the contrasting knowledge about human racial differences and racial extinction presumed to inhere in them; and that such professional conflicts helped in practice to confirm the centrality of race in colonial attitudes and strategies towards indigenous Australians. In Chapter Five, Stephanie Anderson makes a single episode - an actual encounter between three Aborigines and several French anthropologists in Paris in 1885 - a synecdoche for the discursive colonization of Aboriginal Australians and Tasmanians by French raciology. However, she is alert both to ambiguities in the encounter and its representation and to tensions in the wider discourse between physicalist and ethnographic approaches. The Australians were objectified as characteristic specimens of a supposedly inferior, autochthonous racial type and yet traces of their individual personalities, capabilities, and emotional state punctuated the scientists' bleak, 
anthropometrical descriptions. So too, the bewildering physical and cultural variety apparent in ethnographic reports of actual Aboriginal people defied simplistic premises about racial homogeneity or racial purity and introduced doubt and contradiction to raciological analysis, problematizing its core assumption of natural racial hierarchy and ultimately the concept of race itself.

Part Four introduces new complexity into this story of uncertainty and rifts in nineteenth-century scientific discourses on race by extending the inquiry into the early twentieth century and addressing a striking lacuna in many histories of racial thinking — the ambivalent relationships between British Evangelical humanism and the science of race, ranging across a spectrum from antagonism, to compromise, to collaboration. In Chapter Six, Helen Gardner tracks a series of nineteenth-century debates in Britain and colonial Australia over the universal presence or racially selective absence of the human capacity for religious belief and for becoming Christian. Initially contested as evidence for human unity or plural origins, by late in the century the purported existence or lack of the 'faculty of faith' - particularly among Aboriginal Australians was taken by competing strands of evolutionist anthropology as a sign of the stage of psychic development reached by different races. Such evolutionist arguments provoked both opposition and qualified adherence among Evangelical missionaries who had lived and worked with indigenous communities in Oceania. In Chapter Seven, Christine Weir provides another variant on the core themes of normalization, fracture, and recursion with respect to race by mapping entangled rival discourses - religious or secular, scientific or public - on human unity and difference in the late nineteenth and early twentieth centuries. In key texts by Evangelical missionaries, naturalized racial terminology and social evolutionist assumptions jostled with the humanizing imprint of personal acquaintance with individual Pacific Islanders and with Christian distrust of the concepts of natural racial hierarchy or the absolute separation of races. In the aftermath of World War I, interpersonal experience in the mission field informed an emerging humanist internationalism which confronted the strident biological determinism of white supremacist, 'world eugenics' rhetoric emanating from the United States. In Australia, a parallel contest between paternalist internationalism and hardline colonial self-interest developed in the course of debates about Australia's League of Nations' mandate over former German New Guinea.

Part Five recapitulates the linked themes of racial purity, miscegenation, and hybridity, transposed to pragmatic colonial and national settings in Oceania which exemplify the ambiguous flows between abstract racial theorizing, popular race pride or anxieties about racial integrity, and colonial praxis. In Chapter Eight, Vicki Luker concludes the volume with a comparative investigation into a colonial puzzle - the markedly discrepant attitudes to the 'half-caste' expressed in diverse settings in the South Pacific during the interwar period. Emphasizing contexts over theory, she probes the varied pragmatic import of latitude and 
relative chronology, sexualized racial ambivalence about miscegenation and half-castes, and institutional or environmental imperatives. She shows clearly that, if the science of race did not necessarily impinge directly on popular consciousness or colonial policy, ${ }^{41}$ its eclectic theories on hybridity and acclimatization were repeatedly invoked in divergent positions taken on racial assimilation or racial purity in the new nations of Australia and New Zealand or in the colonies of Western Samoa and Fiji. Here, too, as in other settings discussed in this collection, the ambiguities of the idea of race itself and the deeply flawed logic of its science were patent, as were the tensions and fractures in the dissonant discourses that race at once infiltrated and informed.

\section{References}

Anderson, Kay. 2007. Race and the Crisis of Humanism. London and New York: Routledge.

Anderson, Warwick. 2000. The Possession of Kuru: Medical Science and Biocolonial Exchange. Comparative Studies in Society and History 42:713-44. 2002. The Cultivation of Whiteness: Science, Health and Racial Destiny in Australia. Carlton, VIC: Melbourne University Press.

Ballantyne, Tony, ed. 2004. Science, Empire and the European Exploration of the Pacific. Aldershot, Hants, UK, and Burlington, VT: Ashgate.

Ballard, Chris. 2001. Collecting Pygmies: the 'Tapiro' and the British Ornithologists' Union Expedition to Dutch New Guinea, 1910-1911. In Hunting the Gatherers: Ethnographic Collectors, Agents and Agency in Melanesia, 1870s-1930s, ed. Michael O'Hanlon and Robert L. Welsch, 127-54. New York and Oxford: Berghahn Books. . 2006. Strange Alliance: Pygmies in the Colonial Imaginary. World Archaeology 38:133-51.

Bernasconi, Robert, ed. 2001a. Concepts of Race in the Eighteenth Century, 8 vols. Bristol, UK: Thoemmes. . 2001b. Race. Malden, MA, and Oxford: Blackwell. . 2002. American Theories of Polygenesis, 7 vols. Bristol, UK: Thoemmes. . 2003. Race and Anthropology, 9 vols. Bristol, UK: Thoemmes. 2005. Race, Hybridity, and Miscegenation, 3 vols. Bristol, UK: Thoemmes.

Bernasconi, Robert, and Sybol Cook, ed. 2003. Race and Racism in Continental Philosophy. Bloomington: Indiana University Press. 
Bibliothèque nationale de France. 2004. Domeny de Rienzi, Grégoire Louis (1789-1843). Catalogue en ligne BP-OPALE PLUS Notice no. FRBNF 13325735. Paris: Bibliothèque nationale de France. Accessed 16 December 2004, online <http://www.bnf.fr/pages/zNavigat/frame/catalog.htm>.

Blanckaert, Claude. 1988. On the Origins of French Ethnology. In Bones, Bodies, Behavior: Essays on Biological Anthropology, ed. George W. Stocking, Jr., 18-55. Madison: University of Wisconsin Press.

2003a. Les conditions d'émergence de la science des races au début du XIX ${ }^{e}$ siècle. In L'idée de 'race' dans les sciences humaines et la littérature (XVIII et XIX siècles), ed. Sarga Moussa, 133-49. Paris: L'Harmattan. 2003b. Of Monstrous Métis? Hybridity, Fear of Miscegenation, and Patriotism from Buffon to Paul Broca. In The Color of Liberty: Histories of Race in France, ed. Sue Peabody and Tyler Stovall, 42-70. Durham, NC: Duke University Press. 2006. 'Notre immortel naturaliste': Buffon, la science de l'homme et l'écriture de l'histoire. In Buffon: de l'Homme, ed. Michèle Duchet, 407-67. Paris: L'Harmattan.

Bory de Saint-Vincent, Jean-Baptiste-Geneviève-Marcellin. 1827 [1825]. L'homme (homo): essai zoologique sur le genre humain, 2 vols. 2nd edition. Paris: Rey et Gravier.

Brantlinger, Patrick. 2003. Dark Vanishings: Discourse on the Extinction of Primitive Races, 1800-1930. Ithaca, NY, and London: Cornell University Press.

Bravo, Michael T. 1996. Ethnological Encounters. In Cultures of Natural History, ed. N. Jardine, J.A. Secord, and E.C. Spary, 338-57. Cambridge: Cambridge University Press.

Bravo, Michael, and Sverker Sörlin, ed. 2002. Narrating the Arctic: a Cultural History of Nordic Scientific Practices. Canton, MA: Science History Publications.

[Brosses, Charles de]. 1756. Histoire des navigations aux terres australes contenant ce que l'on sçait des mours \& des productions des contrées découvertes jusqu'à ce jour ..., 2 vols. Paris: Durand.

Brown, George. 1887. Papuans and Polynesians. Journal of the Anthropological Institute of Great Britain and Ireland 16:311-27.

1910. Melanesians and Polynesians: their Life-Histories Described and Compared. London: Macmillan and Co. 
Brué, Adrien-Hubert. 1816 [1814]. Océanie ou cinquième partie du monde, comprenant l'Archipel d'Asie, l'Australasie, la Polynésie, \&. ${ }^{a}$ In Grand atlas universel, ou collection de cartes encyprotypes, générales et détaillées des cinq parties du monde, carte 36. Engraving. 2nd edition. Paris: Desray. David Rumsey Map Collection. Fulton, MD: Cartography Associates. Accessed 14 September 2007, online $<$ http://www.davidrumsey.com/detail?id=1-1-25585-1040021\&name=Oceanie $>$.

Caneva, Kenneth L. 1998. Objectivity, Relativism, and the Individual: a Role for a Post-Kuhnian History of Science. Studies in History and Philosophy of Science 29:327-44.

Codrington, R.H. 1881. Religious Beliefs and Practices in Melanesia. Journal of the Royal Anthropological Institute 10:261-316. 1891. The Melanesians: Studies in their Anthropology and Folk-lore. Oxford: Clarendon Press.

Copans, Jean, and Jean Jamin, ed. 1978. Aux origines de l'anthropologie française: les mèmoires de la Société des observateurs de l'homme en l'an VII. Paris: Le Sycomore.

Cowlishaw, Gillian K. 2000. Censoring Race in 'Post-colonial' Anthropology. Critique of Anthropology 20:101-23.

Dalrymple, Alexander. 1770-1. An Historical Collection of the Several Voyages and Discoveries in the South Pacific Ocean, 2 vols. London: J. Nourse, T. Payne and P. Elmsley.

Domeny de Rienzi, Grégoire Louis. 1836-8. Océanie ou cinquième partie du monde: revue géographique et ethnographique de la Malaisie, de la Micronésie, de la Polynésie et de la Mélanésie, offrant les résultats des voyages et des découvertes de l'auteur et de ses devanciers, ainsi que ses nouvelles classifications et divisions de ces contrées, 3 vols. Paris: Firmin Didot frères.

Douglas, Bronwen. 1999. Science and the Art of Representing 'Savages': Reading 'Race' in Text and Image in South Seas Voyage Literature. History and Anthropology 11:157-201. . 2003. Seaborne Ethnography and the Natural History of Man. Journal of Pacific History 38:3-27.

2005. 'Cureous Figures': European Voyagers and Tatau/Tattoo in Polynesia, 1595-1800. In Tattoo: Bodies, Art and Exchange in the Pacific and the West, ed. Nicholas Thomas, Anna Cole, and Bronwen Douglas, 32-52. London and Durham, NC: Reaktion Books and Duke University Press. 
. 2006. Slippery Word, Ambiguous Praxis: 'Race' and Late 18th-Century Voyagers in Oceania. Journal of Pacific History 41:1-29. . 2007. The Lure of Texts and the Discipline of Praxis: Cross-Cultural History in a Post-Empirical World. Humanities Research, 14:11-30. Online $<$ http://epress.anu.edu.au/hrj2007_citation.html>. . 2008. Voyages, Encounters, and Agency in Oceania: Captain Cook and Indigenous People. History Compass 6 (3):712-37. n.d. Encountering Agency: Islanders, European Voyagers, and the Production of Race in Oceania. In Changing Contexts - Shifting Meanings: Transformations of Cultural Traditions in Oceania, ed. Elfriede Hermann. Honolulu: University of Hawai'i Press.

Dumont d'Urville, Jules-Sébastien-César. 1832. Sur les îles du Grand Océan. Bulletin de la Société de Géographie 17:1-21.

Duyker, Edward. 2003. Citizen Labillardière: a Naturalist's Life in Revolution and Exploration (1755-1834). Carlton South, VIC: Miegunyah Press. . 2006. François Péron, an Impetuous Life: Naturalist and Voyager. Carlton South, VIC: Miegunyah Press.

Eigen, Sara, and Mark Larrimore, ed. 2006. The German Invention of Race. Albany: State University of New York Press.

Eisler, William. 1995. The Furthest Shore: Images of Terra Australis from the Middle Ages to Captain Cook. Cambridge: Cambridge University Press.

Ellingson, Ter. 2001. The Myth of the Noble Savage. Berkeley: University of California Press.

Ellis, William. 1831 [1829]. Polynesian Researches, During a Residence of Nearly Eight Years in the Society and Sandwich Islands, 4 vols. 2nd edition. London: Fisher, Son, \& Jackson.

Erskine, John Elphinstone. 1853. Journal of a Cruise among the Islands of the Western Pacific ... in Her Majesty's Ship Havannah. London: John Murray.

Fine, Oronce [Oronteus Finaeus]. 1531. Nova, et Integra Universi Orbis Descriptio. Woodcut. [Paris: Christian Wechel]. DL Q53/2. Sydney: Mitchell Library. Accessed 18 April 2008, online <http://www.nla.gov.au/exhibitions/southland/maps-1531_Fine.html>.

Fisher, Robin, and Hugh Johnston, ed. 1993. From Maps to Metaphors: the Pacific World of George Vancouver. Vancouver: UBC Press.

Frost, Alan. 1976. The Pacific Ocean: the Eighteenth Century's 'New World'. Studies on Voltaire and the Eighteenth Century 151-5:779-822. 
Gardner, Helen Bethea. 2006. Gathering for God: George Brown in Oceania. Dunedin, NZ: University of Otago Press.

Gascoigne, John. 2007. The German Enlightenment and the Pacific. In The Anthropology of the Enlightenment, ed. Larry Wolff and Marco Cipolloni, 141-71.Stanford, CA: Stanford University Press.

Gelpke, J.H.F. Sollewijn. 1993. On the Origin of the Name Papua. Bijdragen Tot de Taal-, Land-, en Volkenkunde 149:318-32.

Goos, Pieter. 1668 [1666]. The Sea-Atlas or the Watter-World, Wherein are described all the Sea Coasts of the Knowne World ... Amsterdam: Pieter Goos.

Gould, Stephen Jay. 1996 [1981]. The Mismeasure of Man. 2nd edition. New York: Norton.

Great Britain, Foreign Office. 1920. British Possessions in Oceania. London: HM Stationery Office.

Hale, Horatio. 1846. United States Exploring Expedition: during the years 1838, 1839, 1840, 1841, 1842, under the Command of Charles Wilkes, U.S.N., vol. 6. Ethnography and Philology. Philadelphia: Lea \& Blanchard.

Hall, Catherine. 2002. Civilising Subjects: Colony and Metropole in the English Imagination, 1830-1867. Chicago and London: University of Chicago Press.

Hannaford, Ivan. 1996. Race: the History of an Idea in the West. Washington, DC, and Baltimore, MD: Woodrow Wilson Center Press and Johns Hopkins University Press.

Harrison, Faye V. 1995. The Persistent Power of 'Race' in the Cultural and Political Economy of Racism. Annual Review of Anthropology 24:47-74.

Hau'ofa, Epeli. 1993. Our Sea of Islands. In A New Oceania: Rediscovering Our Sea of Islands, ed. Eric Waddell, Vijay Naidu, and Epeli Hau'ofa, 2-16. Suva, Fiji: School of Social and Economic Development, University of the South Pacific. . 1998. The Ocean in Us. Contemporary Pacific 10:392-410.

Herbert, Christopher. 1991. Culture and Anomie: Ethnographic Imagination in the Nineteenth Century. Chicago: University of Chicago Press.

Higham, Thomas, Atholl Anderson, and Chris Jacomb. 1999. Dating the First New Zealanders: the Chronology of Wairau Bar. Antiquity 73 (280):420-7.

Hilliard, David. 1978. God's Gentlemen: a History of the Melanesian Mission, 1849-1942. St Lucia: University of Queensland Press. 
Home, R.W., ed. 1988. Australian Science in the Making. Cambridge: Cambridge University Press.

Inglis, John. 1887. In the New Hebrides: Reminiscences of Missionary Life and Work, Especially on the Island of Aneityum, from 1850 till 1877. London: Thomas Nelson and Sons.

Jolly, Margaret. 2001. Imagining Oceania: Indigenous and Foreign Representations of a Sea of Islands. In Framing the Pacific in the $21^{\text {st }}$ Century: Co-existence and Friction, ed. Daizaburo Yui and Yasua Endo, 29-48. Tokyo: Center for Pacific and American Studies, University of Tokyo.

2007. Imagining Oceania: Indigenous and Foreign Representations of a Sea of Islands. Contemporary Pacific 19:508-45.

Jones, Rhys. 1988. Images of Natural Man. In Baudin in Australian Waters: the Artwork of the French Voyage of Discovery to the Southern Lands 1800-1804, ed. Jacqueline Bonnemains, Elliott Forsyth, and Bernard Smith, 35-64. Melbourne: Oxford University Press.

Kaiwar, Vasant, and Sucheta Mazumdar, ed. 2003. Essays on Race, Orient, Nation. Durham, NC: Duke University Press.

Kidd, Colin. 2006. The Forging of Races: Race and Scripture in the Protestant Atlantic World, 1600-2000. Cambridge: Cambridge University Press.

Kohn, Marek. 1996 [1995]. The Race Gallery: the Return of Racial Science. London: Vintage.

Kuhn, Thomas S. 1970 [1962]. The Structure of Scientific Revolutions. 2nd edition. Chicago: University of Chicago Press.

Lesson, René-Primevère. 1829 [1826]. Mémoire sur les races humaines répandues sur les îles du Grand-Océan, et considérées sous les divers rapports physiologiques, naturels et moraux. In Voyage médical autour du monde, exécuté sur la corvette du roi La Coquille ... pendant les années 1822, 1823, 1824 et 1825 ..., 153-228. Paris: Roret.

Lesson, René-Primevère, and Prosper Garnot. 1826-30. Voyage autour du monde ... sur la corvette de Sa Majesté, La Coquille, pendant les années 1822, 1823, 1824 et 1825 ... par L.I. Duperrey. Zoologie, 2 vols. Paris: Arthus Bertrand.

Liebersohn, Harry. 2006. The Travelers' World: Europe to the Pacific. Cambridge, MA: Harvard University Press.

Lincoln, Margarette, ed. 1998. Science and Exploration in the Pacific: European Voyages to the Southern Oceans in the Eighteenth Century. Woodbridge, Suffolk: Boydell Press in association with the National Maritime Museum. 
Littlefield, Alice, Leonard Lieberman, and Larry T. Reynolds. 1982. Redefining Race: the Potential Demise of a Concept in Physical Anthropology. Current Anthropology 23:641-55.

McGregor, Russell. 1997. Imagined Destinies: Aboriginal Australians and the Doomed Race Theory, 1880-1939. Carlton, VIC.: Melbourne University Press.

Mackay, David. 1999. Myth, Science, and Experience in the British Construction of the Pacific. In Voyages and Beaches: Pacific Encounters, 1769-1840, ed. Alex Calder, Jonathan Lamb, and Bridget Orr, 100-13. Honolulu: University of Hawai'i Press.

MacLeod, Roy, and Philip F. Rehbock, ed. 1988. Nature in its Greatest Extent: Western Science in the Pacific. Honolulu, University of Hawaii Press. . 1994. Darwin's Laboratory: Evolutionary Theory and Natural History in the Pacific. Honolulu: University of Hawaii Press.

Malik, Kenan. 1996. The Meaning of Race: Race, History and Culture in Western Society. Basinstoke, Hampshire, UK: Palgrave.

Malte-Brun, Conrad. 1803. Géographie genérale, mathématique et physique. In Edme Mentelle and Conrad Malte Brun, Géographie mathématique, physique et politique de toutes les parties du monde ..., vol. 1, 151-552. Paris: H. Tardieu et Laporte. 1810. Précis de la geographie universelle, ou description de toutes les parties du monde, sur un plan nouveau, d'après les grandes divisions naturelles du globe, vol. 1, Histoire de la géographie. Paris: F. Buisson. 1813. Précis de la geographie universelle, ou description de toutes les parties du monde, sur un plan nouveau, d'après les grandes divisions naturelles du globe ..., vol. 4, Description de l'Inde, de l'Océanique, et de l'Afrique septentrionale. Paris: Fr. Buisson.

1825. Universal Geography, or a Description of all the Parts of the World, on a New Plan, according to the Great Natural Divisions of the Globe ..., tr. unknown, vol. 3, Containing the Description of India and Oceanica. Boston: Wells and Lilly.

Marshall, P.J., and Glyndwr Williams. 1982. The Great Map of Mankind: British Perceptions of the World in the Age of Enlightenment. London: J.M. Dent \& Sons.

Meijer, Miriam Claude. 1999. Race and Aesthetics in the Anthropology of Petrus Camper (1722-1789). Amsterdam-Atlanta, GA: Editions Rodopi.

Mentelle, Edme, and Conrad Malte Brun. 1804. Géographie mathématique, physique et politique de toutes les parties du monde..., vol. 12, Contenant la suite 
de l'Asie et les Terres Océaniques ou la cinquième partie du monde. Paris: Henry Tardieu et Laporte.

Mercator, Gerard. 1587. Orbis Terrae Compendiosa Descriptio ... Engraving. Duysburghi Clivorum: Typis Aeneis. ZM2 100a/1587/1. Sydney: Mitchell Library. Accessed 20 April 2008, online $<$ http://image.sl.nsw.gov.au/cgi-bin/ebindshow.pl?doc $=$ crux/a127;seq=10 $>$.

Monin, Charles V. 1834. Océanie: divisions de l'Océanie. Paris: no publisher. Engraving. MAP T 913/2. Canberra: National Library of Australia. Accessed 27 February 2008, online $<$ http://www.nla.gov.au/apps/cdview?pi=nla.map-t913-2-e > .

Montagu, Ashley. 1997 [1942]. Man's Most Dangerous Myth: the Fallacy of Race. 6th edition. Walnut Creek, CA: AltaMira Press.

Moussa, Sarga, ed. 2003. L'idée de 'race' dans les sciences humaines et la littérature (XVIII $I^{e}$ XIX $X^{e}$ siècles). Paris: L'Harmattan.

Murray, A.W. 1863. Missions in Western Polynesia: Being Historical Sketches of these Missions, from their Commencement in 1839 to the Present Time. London: John Snow. 1874. Wonders in the Western Isles: Being a Narrative of the Commencement and Progress of Mission Work in Western Polynesia. London: Yates and Alexander.

Nordman, Daniel. 2006. Les sciences historiques et géographiques dans l'exploration scientifique de l'Algérie (vers 1840-vers 1860). In Géographies plurielles: les sciences géographiques au moment de l'émergence des sciences humaines (1750-1850), ed. Hélène Blais et Isabelle Laboulais, 235-53. Paris: L'Harmattan.

Nouveau petit Larousse illustré: dictionnaire encyclopédique. 1926. Paris: Librairie Larousse.

O'Gorman, Edmundo. 1961. The Invention of America: an Inquiry into the Historical Nature of the New World and the Meaning of its History. Bloomington: Indiana University Press.

Ortelius, Abraham. 1592 [1589]. Maris Pacifici, (quod vulgó Mar del Zur) .... In Theatrum Orbis Terrarum. 4th edition. Antwerp: Plantjin. Engraving. MAP NK 1528. Canberra: National Library of Australia. Accessed 16 April 2008, online < http://nla.gov.au/nla.map-nk1528>.

Oxford English Dictionary. 2008. Draft 3rd edition. Oxford: Oxford University Press. Online $<$ http://dictionary.oed.com $>$.

Peabody, Sue, and Tyler Stovall, ed. 2003. The Color of Liberty: Histories of Race in France. Durham, NC: Duke University Press. 
Petit Larousse illustré. 1977. Paris: Librairie Larousse.

Prichard, James Cowles. 1836-47. Researches into the Physical History of Mankind, 5 vols. 3rd edition. London: Sherwood, Gilbert, and Piper. . 1843. The Natural History of Man: Comprising Inquiries into the Modifying Influence of Physical and Moral Agencies on the Different Tribes of the Human Family. London: H. Baillière.

Quoy, Jean-René Constant, and Joseph-Paul Gaimard. 1824. De l'homme: observations sur la constitution physique des Papous. In Voyage autour du monde ... exécuté sur les corvettes de S.M. l'Uranie et la Physicienne, pendant les années 1817, 1818, 1819 et 1820 ... Zoologie, 1-11. Paris: Pillet aîné.

Raj, Kapil. 2000. 18th-Century Pacific Voyages of Discovery, 'Big Science', and the Shaping of an European Scientific and Technological Culture. History and Technology 17:79-98.

Renneville, Marc. 1996. Un terrain phrénologique dans le grand océan (autour du voyage de Dumoutier sur $L^{\prime}$ Astrolabe en 1837-1840). In Le terrain des sciences humaines: instructions et enquêtes ( $X V I I I^{e}-X X^{e}$ siècle), ed. Claude Blanckaert, 89-138. Paris: L'Harmattan.

Richard, Hélène. 1986. Une grande expédition scientifique au temps de la Révolution française: le voyage de d'Entrecasteaux à la recherche de La Pérouse. Paris: CTHS.

Robertson, H.A. 1902. Erromanga the Martyr Isle, ed. John Fraser. London: Hodder and Stoughton.

Sanz, Carlos. 1973. Australia su descubrimiento y denominación: con la reproducción facsimil del memorial número 8 de Quirós en español original, y en las diversas traducciones contemporáneas. Madrid: Dirección General de Relaciones Culturales, Ministerio de Asuntos Exteriores.

Schaffer, Simon. 2007. 'On Seeing Me Write': Inscription Devices in the South Seas. Representations 97:90-122.

Schiebinger, Londa. 2004 [1993]. Nature's Body: Gender in the Making of Modern Science. 2nd edition. New Brunswick, NJ: Rutgers University Press.

Selwyn, George Augustus. 1842-67. Letters from the Bishop of New Zealand. 1842-1867. In Letters from the Bishop of New Zealand, and Others, vol. 1. TS, Auckland: Library of the Auckland Institute and Museum. Microfilm, Canberra: Division of Pacific and Asian History, Australian National University. 
Serres, Etienne-Renaud-Augustin, et al. 1841. Rapport sur les résultats scientifiques du voyage de circumnavigation de l'Astrolabe et de la Zélée. Compte rendu des séances de l'Académie des Sciences 13:643-59.

Sivasundaram, Sujit. 2005. Nature and the Godly Empire: Science and Evangelical Mission in the Pacific, 1795-1850. Cambridge: Cambridge University Press.

Smith, Bernard. 1969 [1960]. European Vision and the South Pacific 1768-1850: a Study in the History of Art and Ideas. Oxford: Oxford University Press. . 1992. Imagining the Pacific: in the Wake of the Cook Voyages. Carlton, VIC: Melbourne University Press at the Miegunyah Press.

Spriggs, Matthew, Sue O'Connor, and Peter Veth. 2006. The Aru Islands in Perspective: a General Introduction. In The Archaeology of the Aru Islands, Eastern Indonesia, ed. S. O'Connor, M. Spriggs, and P. Veth, 1-23. Canberra: ANU E Press. Accessed 5 June 2008, online $<$ http://epress.anu.edu.au/terra_australis/ta22/pdf/ch01.pdf $>$.

Staum, Martin S. 2003. Labeling People: French Scholars on Society, Race, and Empire, 1815-1848. Montreal \& Kingston: McGill-Queen's University Press.

Stepan, Nancy. 1982. The Idea of Race in Science: Great Britain 1800-1960. London: Macmillan.

Stocking, George W., Jr. 1968. Race, Culture and Evolution: Essays in the History of Anthropology. New York: Free Press. 1973. From Chronology to Ethnology: James Cowles Prichard and British Anthropology 1800-1850. In James Cowles Prichard, Researches into the Physical History of Man, ed. George W. Stocking, Jr., ix-cx. Chicago: University of Chicago Press. 1987. Victorian Anthropology. New York: Free Press. ed. 1988. Bones, Bodies, Behavior: Essays on Biological Anthropology. Madison: University of Wisconsin Press.

Stoler, Ann Laura. 1995. Race and the Education of Desire: Foucault's History of Sexuality and the Colonial Order of Things. Durham, NC: Duke University Press. 2002. Carnal Knowledge and Imperial Power: Race and the Intimate in Colonial Rule. Berkeley: University of California Press.

Stoler, Ann Laura, and Frederick Cooper. 1997. Between Metropole and Colony: Rethinking a Research Agenda. In Tensions of Empire: Colonial Cultures in a Bourgeois World, ed. Frederick Cooper and Ann Laura Stoler, 1-56. Berkeley: University of California Press. 
Thomas, Nicholas. 1989. The Force of Ethnology: Origins and Significance of the Melanesia/Polynesia Division. Current Anthropology 30:27-41. . 1994. Colonialism's Culture: Anthropology, Travel and Government. Cambridge: Polity Press. 1996. 'On the Varieties of the Human Species': Forster's Comparative Ethnology. In Johann Reinhold Forster, Observations Made During a Voyage Round the World, ed. Nicholas Thomas, Harriet Guest, and Michael Dettelbach, xxiii-xl. Honolulu: University of Hawaii Press. . 1997. In Oceania: Visions, Artifacts, Histories. Durham, NC: Duke University Press. . 2002. Dumont d'Urville's Anthropology. In Lure of the Southern Seas: the Voyages of Dumont d'Urville 1826-1840, ed. Susan Hunt, Martin Terry, and Nicholas Thomas, 53-66. Sydney: Historic Houses Trust of New South Wales.

Todorov, Tzvetan. 1989. Nous et les autres: la réflexion française sur la diversité humaine. Paris: Editions du Seuil.

Turnbull, Paul. 1998. 'Outlawed Subjects': the Procurement and Scientific Uses of Australian Aboriginal Heads, ca. 1803-1835. Eighteenth-Century Life 22:156-71.

. 2001. 'Rare Work Amongst the Professors': the Capture of Indigenous Skulls Within Phrenological Knowledge in Early Colonial Australia. In Body Trade: Captivity, Cannibalism and Colonialism in the Pacific, ed. Barbara Creed and Jeanette Hoorn, 3-23. New York and Annandale, NSW: Routledge and Pluto Press.

Turner, George. 1861. Nineteen Years in Polynesia: Missionary Life, Travels, and Researches in the Islands of the Pacific. London: John Snow.

Vanuatu, Tourism Office. 2006. National Flag and Emblem of Vanuatu. Vanuatu Islands. Port Vila: Vanuatu Tourism Office and Government of Vanuatu. Accessed 21 August 2006, online $<$ http://www.vanuatutourism.com/vanuatu/export/ sites/VTO/en/resources/flag_emblem.html>.

Vetter, Jeremy. 2006. Wallace's Other Line: Human Biogeography and Field Practice in the Eastern Colonial Tropics. Journal of the History of Biology 39:89-123.

Waddell, Eric, Vijay Naidu, and Epeli Hau'ofa, ed. A New Oceania: Rediscovering Our Sea of Islands. Suva, Fiji: School of Social and Economic Development, University of the South Pacific. 
Wheeler, Roxann. 2000. The Complexion of Race: Categories of Difference in Eighteenth-Century British Culture. Philadelphia: University of Pennsylvania Press.

Williams, Glyndwr. 1979. Seamen and Philosophers in the South Seas in the Age of Captain Cook. Mariner's Mirror 65:3-22.

Williams, John. 1837. A Narrative of Missionary Enterprises in the South Sea Islands: with Remarks upon the Natural History of the Islands, Origin, Languages, Traditions, and Usages of the Inhabitants. London: John Snow.

Wilson, Kathleen. 2003. The Island Race: Englishness, Empire and Gender in the Eighteenth Century. London: Routledge.

Wroth, Lawrence C. 1944. The Early Cartography of the Pacific. Papers of the Bibliographical Society of America 38 (2):87-268.

Young, Robert M. 1977. Science Is Social Relations. Radical Science Journal 5 (1977):65-129.

Zimmerman, Andrew. 2001. Anthropology and Antihumanism in Imperial Germany. Chicago: University of Chicago Press.

\section{Notes}

${ }^{1}$ On these themes, see Cowlishaw 2000; Gould 1996; Harrison 1995; Kaiwar and Mazumdar 2003; Kohn 1996; Littlefield, Lieberman, and Reynolds 1982; Malik 1996; Montagu 1997.

2 A sample of books on aspects of the history of race published or republished during this period includes Bernasconi 2001b; Bernasconi and Cook 2003; Brantlinger 2003; Eigen and Larrimore 2006; Ellingson 2001; Gould 1996; Hall 2002; Hannaford 1996; Kidd 2006; Meijer 1999; Montagu 1997; Moussa 2003; Peabody and Stovall 2003; Schiebinger 2004; Staum 2003; Stoler 1995, 2002; Wheeler 2000; Wilson 2003; Zimmerman 2001; see also Bernasconi's valuable facsimile editions of key eighteenth- and nineteenth-century texts on race $(2001 \mathrm{a}, 2002,2003,2005)$.

3 See especially the work of Claude Blanckaert (1988, 2003a, 2003b, 2006) and George W. Stocking, Jr. $(1968,1973,1987,1988)$ and recent studies of the significance of field encounters for the human sciences by historians of geography (e.g., Bravo 1996; Bravo and Sörlin 2002; Nordman 2006).

4 See, e.g., Anderson 2007; Brantlinger 2003; Schiebinger 2004; Todorov 1989. Though these works have their virtues, the authors have in different ways sacrificed a precise, discriminative, comparative reading of contemporary texts to derivative analysis of an overarching discourse, presumed deductively to determine or explain aspects of racial thinking. On the other hand, while Nancy Stepan's (1982) pioneer general history of the science of race in Britain is sufficiently empirical and often insightful, it is also marred by inaccuracies of reading and interpretation.

${ }^{5}$ Bernard Smith's groundbreaking studies $(1969,1992)$ traced the genesis of racial thinking with respect to Australia and the Pacific Islands while Nicholas Thomas $(1989 ; 1996 ; 1997: 133-55 ; 2002)$ wrote brief but perceptive histories of the racial classification of Pacific Islanders. See also several recent histories of race in Australia (Anderson 2002; Anderson 2007; McGregor 1997); and incidental references to racial ideas in works on the science or the art of particular voyages in the region (Copans and Jamin 1978; Duyker 2003, 2006; Fisher and Johnston 1993; Jones 1988; Liebersohn 2006; Richard 1986; Stocking 1968:13-41).

${ }^{6}$ Caneva 1998; cf. Young 1977.

7 Anderson 2007:22-4, 67, 109-12, 197-202, original emphasis. Anderson's only access to my thinking and sole reference to my work are to an unpublished conference paper - an ancestral version of the first two chapters of this collection.

8 The phrase is Claude Blanckaert's (2003:43); see also Kohn 1996:2-3; Stepan 1982:xiv-xvi. 
9 See also Anderson 2007; Copans and Jamin 1978; Frost 1976:810-22; Marshall and Williams 1982; Smith 1969; Williams 1979. There is growing scholarly interest in the significance of Oceanic field experience in the construction of scientific knowledge generally (e.g., Anderson 2000; Ballantyne 2004; Gascoigne 2007; Home 1988; Liebersohn 2006; Lincoln 1998; Mackay 1999; MacLeod and Rehbock 1988, 1994; Raj 2000; Renneville 1996; Schaffer 2007; Staum 2003; Vetter 2006).

${ }^{10}$ For the limited geographic span of Oceania in English usages, see Great Britain Foreign Office 1920; and Oxford English Dictionary 2008 which defines the word thus: 'Oceania' - '(A collective name for) the islands and island-groups of the Pacific Ocean and its adjacent seas, including Melanesia, Micronesia, and Polynesia, and sometimes also Australasia and the Malay archipelago' (my emphasis). The most notable indigenous reclaimant of this restricted sense of Oceania is Epeli Hau'ofa (1993:8) for whom the term signified 'a sea of islands with their inhabitants' (see also Hau'ofa 1998; Waddell, Naidu, and Hau'ofa 1993; Jolly 2001, 2007). Hau'ofa (1998:403-4) explicitly excluded the Philippines and Indonesia from Oceania because they 'are adjacent to the Asian mainland' and because they 'do not have oceanic cultures'. 11 Higham, Anderson, and Jacomb 1999:426; Spriggs, O'Connor, and Veth 2006:9-10.

12 Eisler 1995:12-54; Mentelle and Malte-Brun 1804:357-63. With 'America' designated the quarta pars, 'fourth part', of the globe and its fourth 'continent' (O'Gorman 1961:117-33, 167-8), any imagined southern land must henceforth logically have been the fifth part or fifth continent. The designation 'fifth part of the world' appears on the title page of the first Latin translation (1612) of a memorial to the King of Spain by Pedro Fernández de Quirós (1563?-1615) who in 1595 and 1606 had crossed the Mar del Sur, 'South Sea', from Peru on two voyages of exploration, colonization, and evangelism. However, the phrase 'fifth part' is not used in Quirós's original Spanish text of 1610 which refers to the 'hidden' southern part as comprising 'a quarter of all the globe' (Sanz 1973:37-8, 83).

13 [Brosses] 1756, I:77-80. See, e.g., the map by Abraham Ortelius (1527-1598) in which 'Terra Australis, or Magellanica, not yet revealed' encompasses much of the southern portion of the globe (Ortelius 1592). The classical theory that a large land mass must exist in the southern hemisphere to counterbalance those in the north was enthusiastically revived by Renaissance cartographers (Wroth 1944:163-74). The French mathematician Oronce Fine (1494-1555) first used the term 'Terra Australis', annotated as 'recently discovered, but not yet fully known', in his world map of 1531. In 1569, the Flemish cartographer Gerard Mercator (1512-1594) famously promoted the idea of a vast 'southern continental region' (Eisler 1995:37-9) and he added the label 'Terra Australis' to his world map of 1587 with the note: 'Some call this southern continent the Magellanic region after its discoverer'. Eight decades later, the Dutch cartographer Pieter Goos (c. 1616-1675) treated sceptically the 'cal[1] for a fifth part of the world Terra Australis or Magellanica' and left blank the far southern portion of his world map (1668:[7], map 1). Yet most cartographers and geographers, including Brosses and the Scottish hydrographer Alexander Dalrymple (1737-1808), clung to a hopeful belief in the necessary existence of an 'immense' southern continent as a 'counterweight' to the great northern land masses until definitively proven wrong by James Cook ([Brosses] 1856, I:13-16; Dalrymple 1770-1, I:xxii-xxx).

14 Brué 1816; Mentelle and Malte-Brun 1804:362-3, 463-4.

15 Dumont d'Urville 1832; Serres et al. 1841:652. Dumont d'Urville commanded the expedition of the Astrolabe to the Pacific in 1826-29 and circumnavigated the globe twice - as first lieutenant under Louis-Isidore Duperrey (1786-1865) on the Coquille (1822-25) and in command of the Astrolabe and the Zélée (1837-40). Domeny de Rienzi (1836-8, I:1-3) claimed wide experience in western Oceania acquired during 'five voyages' as an independent traveller, particularly in the Malay Archipelago, but was reputedly an 'illusionist, creator of a fantasmagoric autobiography' (Bibliothèque nationale de France 2004).

16 'Oceania or fifth part of the world including the Asian Archipelago, Australasia, Polynesia, etc... 1814' (Brué 1816).

17 Lesson and Garnot 1826-30, I:2, note 1; Lesson 1829:156-65, 216-17, note 1; Malte-Brun 1810:495; 1813:229; Prichard 1837-46, I:xviii, xix, 251, 255, 298; V:1-3; 1843:326.

18 Williams 1837:7-8, 503-4; see also Brown 1887:320; Inglis 1887:4; Murray 1863, 1874; Turner 1861.

19 'Map illustrating the memoir of Captain d'Urville on the islands of the Great Ocean' (Dumont d'Urville 1832: frontispiece).

${ }^{20}$ Malte-Brun 1803:548; 1813:228, 244; Mentelle and Malte-Brun 1804:474, 577, 612, 620, original emphasis.

${ }^{21}$ Since the French term Papou or Papoua does not always translate exactly into English 'Papuan', I retain the French forms as used and indicate their particular import.

22 Bory de Saint-Vincent 1827, I:82, 94-7, 273-318, 297, 306, 318-28; II:104-13. 


\section{Foreign Bodies}

${ }^{23}$ Bory de Saint-Vincent 1827, I:84, 99-101, 299, 304-6, 308-18; II, 108; Quoy and Gaimard 1824; Lesson and Garnot 1826-30.

24 Lesson 1829:157, 168, 202-5.

25 Ballard 2006; Gelpke 1993:326-30; see Chapters Two (Douglas) and Three (Ballard), this volume.

26 Dumont d'Urville 1832:6, 11, 14-15.

27 Hilliard 1978:12-13, 23; Selwyn to his father, 15 Sep. 1849, in Selwyn 1842-67:216-19, 225-7, 230.

28 Codrington 1881:261; 1891; Prichard 1836-47, V:4, 212-13, 282, 283.

29 'Oceania: divisions of Oceania' (Monin 1834).

30 Monin 1834.

31 Gardner 2006:105-27; Herbert 1991:155-203; Sivasundaram 2005; Stocking 1987:8-109; see Chapters Six (Gardner) and Seven (Weir), this volume.

32 Moussa 2003; Staum 2003; see Chapters Two (Douglas) and Five (Anderson), this volume.

33 E.g., Brown 1887:312, 320; 1910; Ellis 1831, I:78-9; Erskine 1853:2, 4, 13, 241; Inglis 1887:5; Robertson 1902:1; Williams 1837:503-4, 512. See also Gardner 2006:114-20; Kidd 2006:121-67.

34 See, e.g., Nouveau petit Larousse illustré 1926:1571-2.

35 Great Britain Foreign Office 1920:37, 38, 120.

36 Petit Larousse illustré 1977:1569.

37 E.g., according to the exegesis of the colour symbolism of the Vanuatu national flag on the official web site of the Vanuatu Tourism Office (2006), the colour black symbolizes 'Melanesia and the Melanesian race'.

38 See Stoler and Cooper 1997; Thomas 1994.

${ }^{39}$ For detailed correlations of episodes in the history of racial thinking with the ethnohistory of particular encounters in Oceania, see Ballard 2001, 2006; Douglas 1999, 2003, 2005, 2006, 2007, 2008, n.d.; Turnbull 1998, 2001.

40 I use the terms 'paradigm' and 'normal science' in Thomas Kuhn's (1970) sense of a broad conceptual framework shared by a disciplinary community of scientists and reified as dogma.

${ }^{41}$ See also Anderson 2002:3-4. 